\title{
Environmental Contamination by Taenia Eggs in Iringa Rural District, Tanzania
}

\author{
Mwita Chacha J*, Tesha Julius and Gamba Nkwengulila
}

Department of Zoology and Wildlife Conservation, P.O. Box 35064, University of Dar Es Salaam, Tanzania

\begin{abstract}
Cysticercosis and Taeniosis are global health problems with impacts on human beings and the development of the livestock industry. This study tested the presence of Taenia eggs in the soil of two villages in Iringa rural district, Tanzania. No recognizable Taenia egg was found, though those found were difficult to identify due to absorption of the flotation fluid which made them dark with difficulties to see the innermost structures. In view of their sizes (30 - 40 microns in diameter) these eggs were considered to be of Taenia spp. In addition, eggs from four geo-helminth species were identified namely; Ascaris lumbricoides, Schistosoma mansoni, Strongyloides stercoralis and Trichuris trichiura eggs. The frequency of T. trichiura was $81.97 \%$, Ascaris lumbricoides was $8.2 \%$, unidentified eggs $6.01 \%$, Strongyloides stercoralis $3.3 \%$ and Schistosoma mansoni was $0.5 \%$. The most contaminated sites were backyard with a prevalence of $30.1 \%$ followed by west disposal site (WDS) $25.7 \%$, open defaecation area (ODA) $24.0 \%$ and the least was toilet $20.2 \%$. About 31 (31\%) samples had no eggs. The findings revealed that the environment of Izazi village was more contaminated by geohelminth eggs (19.4\%) than that of Migoli village (12.1\%) and that higher moisture content in soils favors the growth, development, spread and transmission of geo-helminth eggs.
\end{abstract}

Keywords: Environment, Taenia eggs, Iringa rural, Tanzania.

\section{INTRODUCTION}

Taeniasis is a parasitic disease of the human intestinal tract caused by the adult stage of the closely related tapeworms Taenia solium, Taenia saginata saginata, and Taenia saginata asiatica. After ingestion, the cyst reaches the human intestine, where it develops into an adult tapeworm, releasing proglottids filled with eggs that are passed in the stools [1]. Environmental contamination with Taenia eggs results therefore when human stools are not properly disposed. Consequently, the eggs are further ingested by the intermediate hosts ending in development of cysts in soft tissues, a disease known as cysticercosis in cattle and pigs [2, 3]. Unlike $T$. saginata eggs, humans may serve as intermediate hosts for $T$. solium via contaminated environment causing neurocysticercosis, a major cause of seizures and epilepsy in developing countries [4].

Neurocysticercosis is highly endemic in Latin America, Asia, and Africa, especially in those countries where domestic pig husbandry is practiced [5]. In Tanzania porcine cysticercosis was detected in the late 1980s. Since then several studies have been conducted in the northern highlands (Arusha, Moshi, Mbulu) and in the southern highlands (Iringa, Chunya and Songea) where more than $60 \%$ of the

*Address correspondence to this author at the Department of Zoology and Wildlife Conservation, P.O. Box 35064, University of Dar Es Salaam, Tanzania; Tel: 25522 2410462; Fax: 25522 2410480/2650244;

E-mail: mwitachacha@udsm.ac.tz country's pigs are raised [6]. In the northern highlands, a retrospective study of slaughter slab records in Mbulu district from 1985 to 1989 indicates a prevalence ranging from 0.41 to $4.88 \%$ [6]. Another study by postmortem survey of pigs slaughtered at different slabs indicated that $4.5-37.7 \%$ were infected [7]. In a recent study conducted in Mbulu district of northern Tanzania revealed the overall prevalence of porcine cysticercosis to be $7.3 \%$ [8] which is lower than that of $17.4 \%$ reported previously in 21 villages of Mbulu district [9]. In this study it was observed that out of the six wards included in the clusters, three (Sanu, Kainam, Murray) and one (Gehandu) were at a very high or high risk of infection, respectively, while two wards (Bargish, Tlawi) were at a low risk of infection. The prevalence study also identified Sanu and Kainam as risky wards (Risk Rate (RR) $=4.2$ and 2.0, respectively) while the remaining four wards were identified by this method as low risk wards [8].

The risk factors associated with Taenia solium transmission in humans and pigs in rural areas include; lack of pork inspection at slaughter, free-range husbandry system and indiscriminate defeacation. The present study aimed at investigating the extent of environmental contamination by Taenia eggs and other geohelminths in Iringa rural district. The study compared the occurrence of geo-helminth eggs between different sampling localities (i.e. Backyard, around toilets, open air defecation areas and waste disposal sites) of the study sites and further determined the effects of organic matter on the isolation of Taenia eggs. 


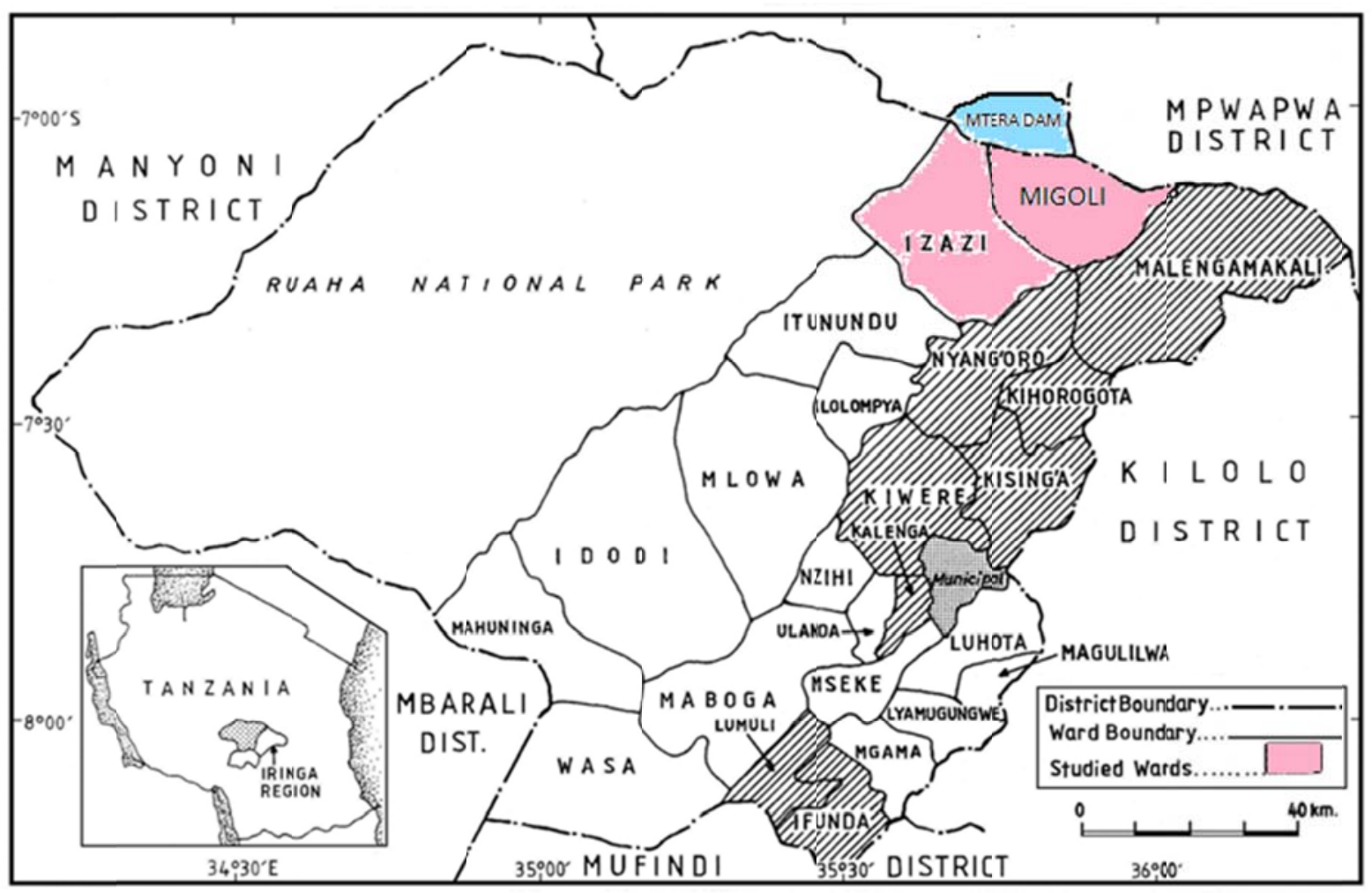

Fig. (1). Iringa rural district showing the location of Izazi and Migoli villages.

Table 1. Prevalence of Geo-Helminths Eggs in Soil Samples from the Two Villages

\begin{tabular}{|c|c|c|c|c|c|}
\hline Village & $\begin{array}{c}\text { No. of } \boldsymbol{A} \text {. Lumbricoides } \\
\text { Eggs. }\end{array}$ & $\begin{array}{c}\text { No. of } \boldsymbol{S . ~ M a n s o n i} \\
\text { Eggs. }\end{array}$ & $\begin{array}{c}\text { No. of } \boldsymbol{S} \text {. Stercoralis } \\
\text { Eggs/Larvae }\end{array}$ & $\begin{array}{c}\text { No. of } \boldsymbol{T} \text {. Trichi- } \\
\text { ura } \text { Eggs. }\end{array}$ & $\begin{array}{c}\text { No. of Unidentified } \\
\text { Eggs. }\end{array}$ \\
\hline \hline Izazi & $10.47 \%$ & 0 & $3.49 \%$ & $81.40 \%$ & $4.65 \%$ \\
\hline Migoli & $6.19 \%$ & $1.03 \%$ & $3.09 \%$ & $82.47 \%$ & $7.22 \%$ \\
\hline
\end{tabular}

A brief explanation on how the current study differs from the previous literature included. Most of the previous studies dealt mainly with porcine cysticercosis rather than environmental contamination. Environmental contamination is a simple way to measure the levels of geohelminth infection in a given population.

\section{MATERIALS AND METHODS}

\section{Study Area}

The study was conducted in an area with a high density of sprawling pigs in Izazi and Migoli villages in Iringa rural district. Izazi village was established in 1974 and the total population and number of households in 1999 village council estimate were 3560 inhabitants distributed among 712 households. The total population of Migoli by 1999 was 3867 with 724 households (Fig. 1).

\section{Soil Sample Collection}

Households for soil sample collections in the two villages were selected based on presence of pigs. Altogether, 96 soil samples were collected from 24 households. Four soil samples (backyard, around toilets, open air defecation areas and waste disposal sites) were collected per household and 12 households were visited per village. The samples were kept in sterile $500 \mathrm{ml}$ plastic bags in cool boxes and transported for analysis to the laboratory of Zoology, University of Dar es salaam.

\section{Isolation of Taenia Eggs from Soil Samples}

Geo-helminth eggs were recovered by the centrifugal flotation method as described in [10], but the floatation fluid (sucrose solution) used had a specific gravity of 1.14 instead of the recommended 1.2 and above. Soil moisture content was determined by the oven drying standard method.

\section{RESULTS}

\section{General Observation}

Eggs from four geo-helminth species were identified in the examined soil samples. These were Ascaris lumbricoides, Schistosoma mansoni, Strongyloides stercolaris and Trichuris trichiura. Prevalence of the recovered geohelminths eggs per village is shown in Table 1. A large number of parasite eggs were recovered from Migoli village. Among the sampling sites, many parasites eggs were recovered in soil samples from the backyards (Table 2). 
Table 2. Prevalence of Geo-Helminths Eggs in Soil Samples of Different Sampling Sites

\begin{tabular}{|c|c|c|c|c|c|}
\hline Site & $\begin{array}{c}\text { No. of } \text { A. Lumbricoides } \\
\text { eggs. }\end{array}$ & $\begin{array}{c}\text { No. of } \boldsymbol{S . ~ M a n s o n i} \\
\text { Eggs. }\end{array}$ & $\begin{array}{c}\text { No. of } \text { S. Stercoralis } \\
\text { Eggs/Larvae }\end{array}$ & $\begin{array}{c}\text { No. of } \text { T. Trichiura } \\
\text { Eggs. }\end{array}$ & $\begin{array}{c}\text { No. of Unidentified } \\
\text { Eggs. }\end{array}$ \\
\hline \hline Backyard & $7.27 \%$ & 0 & $5.45 \%$ & $74.54 \%$ & $12.73 \%$ \\
\hline ODA & $6.82 \%$ & $2.27 \%$ & $6.82 \%$ & $77.27 \%$ & $6.82 \%$ \\
\hline Toilet & $10.81 \%$ & 0 & 0 & $86.47 \%$ & $2.70 \%$ \\
\hline WDS & $8.51 \%$ & 0 & 0 & $91.49 \%$ & 0 \\
\hline
\end{tabular}

Table 3. Prevalence of Geo-Helminths Eggs in Izazi and Migoli Villages Showing Extent of Environmental Contamination

\begin{tabular}{|c|c|c|c|}
\hline Village & Positive Samples & $\begin{array}{c}\text { Samples Contaminated by One } \\
\text { Species of Geo-Helminths Eggs. }\end{array}$ & $\begin{array}{c}\text { Samples Contaminated with More than } \\
\text { One Species of Geo-Helminths Eggs. }\end{array}$ \\
\hline \hline Izazi & 36 & $80.56 \%$ & $19.44 \%$ \\
\hline Migoli & 33 & $87.88 \%$ & $12.12 \%$ \\
\hline
\end{tabular}

Table 4. Summary of Average Moisture Content and the Recovered Eggs

\begin{tabular}{|c|c|c|}
\hline Sites & Average Moisture Content & Total Number of Eggs. \\
\hline \hline Backyard & $1.11 \%$ & 55 \\
\hline ODA & $0.65 \%$ & 44 \\
\hline Toilet & $0.55 \%$ & 37 \\
\hline WDS & $0.52 \%$ & 47 \\
\hline
\end{tabular}

The extent of Environmental Contamination in Migoli and Izazi Villages

The results of the present study show that soil samples from Izazi and Migoli villages were contaminated by one or more species of geo-helminths eggs. Eggs of Trichiura, Ascaris, Schistosoma and Strongyloides were found as individuals or multiple contaminations. A total of 29 soil samples from Izazi and Migoli were each contaminated with a single species of geo-helminth eggs. At Izazi village seven samples $(n=7)$ had more than one species of geo-helminths eggs, whereas at Migoli village only four samples had more than one species of geo-helminths $(n=4)$. The difference however, was statistically insignificant $(\mathrm{t}=0.0917 ; \mathrm{p}=0.005)$. Izazi village was generally found with more geo-helminths positive soil samples $(n=36)$ than Migoli village $(n=33)$ Nevertheless the extent of contamination between the two villages were statistically similar $(\mathrm{t}=0.0947 ; \mathrm{p}=0.005)$ (Table 3$)$.

\section{Environmental Distribution of Geo-helminths Eggs}

The occurrence of eggs from samples were backyard 55 $(30.1 \%)$, ODA $44(24.0 \%)$, toilet $37(20.2 \%)$ and WDS 47 $(25.7 \%)$. About 31 (31\%) of the samples had no eggs. However, the distributions of eggs in all sites sampled were more or less similar $(\mathrm{F}=1.417 ; \mathrm{p}=0.19)$. The frequency of Ascaris lumbricoides was 15 (8.2\%), T. trichiura 150 (81.97\%), Strongyloides stercoralis 6 (3.3\%), Schistosoma mansoni 1 $(0.5 \%)$ and unidentified eggs $11(6.01 \%)$. The frequency of T. trichiura was significantly higher than A. lumbricoides $(\mathrm{t}=0.0004 ; \mathrm{p}=0.05)$; unidentified eggs $(\mathrm{t}=0.001 ; \mathrm{p}=0.05)$ and Strongyloides stercoralis $(\mathrm{t}=0.002 ; \mathrm{p}=0.05)$.

\section{Egg Distribution Per Sampling Site}

The backyard and WDS samples were more contaminated by $T$. trichiura than those from toilets. However, the degree of contamination in backyard and WDS samples were insignificantly higher compared to that from ODA $(t=0.3969 ; \mathrm{p}=0.05)$ and toilet $(\mathrm{t}=0.07 ; \mathrm{p}=0.05)$. The contamination rate in backyard and WDS were statistically simi$\operatorname{lar}(\mathrm{t}=0.4612 ; \mathrm{p}=0.05)$. The distribution of Strongyloides stercoralis was significantly more observed in backyard samples than those in WDS $(\mathrm{t}=0.135 ; \mathrm{p}=0.05)$ and toilet $(t=0.0345 ; \mathrm{p}=0.05)$ samples. However, the total counts in backyard and ODA samples were statistically insignificant $(\mathrm{t}=0.1285 ; \mathrm{p}=0.05)$. While the distribution of $A$. lumbricoides was significantly higher in backyard samples than those from WDS $(\mathrm{t}=0.0188 ; \mathrm{p}<0.05)$, it was similar in ODA $(\mathrm{t}=0.3454 ; \mathrm{p}=0.05)$ and toilet $(\mathrm{t}=0.0818 ; \mathrm{p}=0.05)$ samples. Schistosoma mansoni ova was the least observed in all samples, again, backyard samples revealed high significant contamination by the particular worm eggs than ODA $(\mathrm{t}=0.0116 ; \mathrm{p}=0.05)$, toilet $(\mathrm{t}=0.0306 ; \mathrm{p}=0.05)$ and WDS $(\mathrm{t}=0.0118 ; \mathrm{p}=0.05)$. Regardless of the type of geo-helminthes eggs observed, all collection sites were equally contaminated. The assorted distribution of geo-helminths shows that backyard samples were slightly more contaminated than ODA $(\mathrm{t}=0.0706 ; \mathrm{p}=0.05)$, toilet $(\mathrm{t}=0.0678 ; \mathrm{p}=0.05)$ and WDS $(\mathrm{t}=0.699 ; \mathrm{p}=0.05)$.

\section{Moisture (Organic Matter) Content and Eggs Distribution}

The backyard soil samples were moister than those from ODA $(\mathrm{t}=0.0678 ; \mathrm{p}=0.05)$, though the difference was statistically insignificant. The moisture content from toilet soil 
samples were significantly less than those from backyard $(\mathrm{t}=0.0118 ; \mathrm{p}=0.05)$, similarly those from WDS $(\mathrm{t}=0.00069$; $\mathrm{p}=0.05)$. Furthermore, backyard samples contained significantly high number of eggs than ODA $(t=0.0233 ; p=0.05)$; toilet $(\mathrm{t}=0.0002 ; \mathrm{p}=0.05)$ and WDS $(\mathrm{t}=0.0038 ; \mathrm{p}=0.05)$, however, egg recovery between ODA and WDS were statistically similar $(\mathrm{t}=0.1254 ; \mathrm{p}=0.05)$ (Table 2$)$. The correlation between moisture content and the number of eggs was positive (observed rate $(\mathrm{OR})=0.0125)($ Table 4).

\section{DISCUSSION}

The present study found a considerable population of pigs raised under free range system in households whose environment was highly contaminated by geo-helminths eggs. The study further observed that some of the households had no toilets, if any, were bare/ non-walled, increasing the risk of environmental contamination. Children were found to dispose their wastes in backyards during day plays and when sweeping those grounds they finally dispose off wastes in the waste disposal sites (WDS). Adults defecate on shrubby areas (ODA) during early mornings and nights. Even if children decide to go to toilets, they heap their faeces around the hall or around the wall foots where pigs chew the soil due to the salt taste of urine. Under such circumstances, roaming pigs are likely to feed on feacal materials that at times may contain geo-helminths and or T. solium eggs.

The present study however, did not find any $T$. solium egg from all four sampling sites i.e. backyard, ODA, toilets and WDS in the two villages sampled. Conversely, soil contamination by Trichuris trichiura, Ascaris lumbricoides, strongyloides stercoralis and Schistosoma mansoni were observed. $74 \%$ of the 96 samples were contaminated with more than one species of geo-helminths eggs, whereas $26 \%$ of the examined samples had no egg. This could be due to indiscriminate defeacation by either adult people when drunk or children in play grounds during their day plays. About $7.6 \%$ of the eggs were unidentified; the methodology used might be the source to zero occurrences of $T$. solium eggs.

It is estimated that about one-sixth of the world population is infected by Ascaris lumbricoides [11]. Ascariasis is transmitted when human ingest parasite's infective egg in contaminated food, water or hands. Matured parasites in infected individuals shed eggs which are released out in feaces to the environment where they can persist for more than 10 years [12]. The parasite is distributed in different regions of the world as in Indonesia the prevalence of $73.7 \%$ [13] in Cameroon 54.9\% [14] in Zaria, northern Nigeria [15] and $54.1 \%$ from stool samples and $24.0 \%$ from soil samples of primary school children in Ebenebe town, Anambra state Nigeria [16] were reported. In the present study a prevalence of $10.5 \%$ and $6.2 \%$ were observed from Izazi and Migoli villages respectively.

Schistosoma mansoni are the agents of intestinal schistosomiasis. Human-dwelling parasites release eggs in feaces to the environment, ripe miracidium hatches out of the egg and searches for a suitable freshwater snail. An infected snail can release thousands of sercariae that are capable of infecting man [17]. The parasite is estimated to infect about 83.31 million people worldwide [18]. One sample from Migoli village was found to be contaminated with Schistosoma mansoni egg suggesting the presence of individuals infected with the parasite. The parasite infection is aided by the presence of Mtera Dam where people swim freely and some defeacate in the nearby surroundings. In Ghana, a study done in Atonsu, Kumasi reported presence of schistosoma spp eggs from examined soil samples [19].

Strongyloides stercoralis adult parasitic lives in tunnels in the mucosa of the small intestine of infected individuals and causes strongyloidiasis [20]. These adult parasites lay eggs which are released out in feaces to the environment. Strongyloides stercoralis occurrence were reported in Indonesia with a prevalence of $1.6 \%$ [13] and 5.9\% from stool samples of primary school children in Ebenebe town, Anambra state Nigeria [16]. The present study found the presence of these parasites larva in soil samples from Izazi and Migoli village with the prevalence of $3.5 \%$ and $3.1 \%$ respectively.

Trichuriasis infection occurs through ingestion of Trichuris trichiura eggs which hatch in the small intestines and then move into the wall of the small intestine where it develops into adult worm. The thinner end of the adult worm burrows into the large intestine and the thicker end hangs into the lumen and mates with nearby worms. They then shed eggs which are released in feaces to the environment. Eggs are infective about 2-3 weeks after they are deposited in the soil under proper conditions of warmth and moisture [21]. In this study a large number of Trichuris trichiura eggs were recovered from soil samples of Izazi $(81.4 \%)$ and Migoli (82.4\%). Similar findings were reported from soil samples in Atonsu Kumasi, Ghana [19] and in rural areas of Lodz district Poland with the prevalence of $3.5 \%$ [22].

There were difficulties on identifying several eggs in the present study. These eggs were recovered from soil sample of the two villages Izazi and Migoli. It was difficult to identify these eggs possibly due to absorption of the flotation fluid which made the eggs dark, hence difficulties in examining clearly the innermost structures. It was still difficult to examine them even at higher power magnification, 40X. Considering their sizes ( $30-40$ microns in diameter) these eggs were probably of Taenia spp [23]. The occurrence of the four human parasites eggs and larva in the environment of Izazi and Migoli villages could be attributed by improper use of toilet facilities by the inhabitants of the two villages surveyed. Izazi and Migoli villages are bordered to the north by the Mtera Dam, with fishing as a major economic activity of the area. Unfortunately fishers have a tendency of moving from one location to another in search of fish, and in most cases the new locations have no toilet facilities. This further encourages the habits of indiscriminate disposal of human wastes in Open defeacation areas such as in bushes and shrubby areas. Hence the wide spread of geo-helminths eggs observed in the two villages.

The burden of disease due to soil-transmitted helminth infections (Ascaris lumbricoides, Trichuris trichiura, and the hookworms) may be classified as a lower threshold above which there are detrimental effects on physical and school performance, which might be temporary or permanent and a higher threshold above which there is a risk of clinically overt illness [24]. The results from this study revealed high 
prevalence of the two worm species i.e. A. lumbricoides, and T. trichiura and hence a need to intervene.

The occurrence of more than one species of geo-helminth eggs per sample was higher in Izazi village than in Migoli village. This was due to the complex nature of the ethnic situation of the village. The village population includes indigenous people who mostly do crop cultivation and the newcomers migrated to the area to exploit the fishing potential of the Mtera Dam. These newcomers had established fishermen camps as temporary settlements forming a community with people moving in and out. Due to lack of permanent settlement there are no better sanitary facilities and thus the fishermen have developed habits of indiscriminately disposing off their wastes in shrubby areas surrounding the village. These are the open defecation areas (ODA) whereby adults visit during nights and early morning hours. This habit aided feacal contamination of the surrounding village environment with different species of geo-helminth eggs from infected individuals harboring different species of intestinal parasites from different localities where they originate from.

T. trichiura eggs had the highest frequency followed by A. lumbricoides, S. stercoralis and finally Schistosoma mansoni. With the exception of Schistosoma mansoni which was only found in ODA samples, the backyard, ODA, WDS and toilet were equally contaminated by the rest of the detected worm eggs. Even though the results from the present study contradicts with that by [25] who found high prevalence of Taenia spp. eggs in backyard, toilet, kitchen and washboards, the highest prevalence of intestinal worms eggs from this study area signifies environmental contamination by human faeces. Nevertheless, these findings comply with those of [26] who found no single egg of Taenia spp. other than a high prevalence of $A$. lumbricoides and $T$. trichiura in south-west Cameroon.

Contamination of the environment by these potentially harmful parasites is currently high probably due to the increased population and traditional practices of human waste disposal. Oral faecal age children in the study area depend most of their days playing in backyards as their common play grounds. Some of these backyards are meant for subsistence farming, thus accessible for pet and other livestock. Nevertheless, they are the main sources for vegetables and spices in most of the households. Intermingling of these activities make the environment favourable for geo-helminths development. The fact that Ascaris causes kwashiorkor to children due to inappetence and competing with the host for nutrients in the body, its presence in high prevalence in the study area is of public health concerned.

High moisture content of the backyard also favors development, growth, spread and transmission of geo-helminths. The high moisture content of the backyard sampling site could be due to day to day activities such as washing clothes, household utensils, and small scale cultivation of vegetables for daily uses whereby all these activities involve the use of water which at the end is spilled over the ground as the traditional method to control dust. This habit leaves backyard site moist for most of the time hence providing favorable condition for survival of geo-helminthes [27]. In their study also found moisture content to the soil favor parasite eggs development, growth, spread and transmission. Waste disposal site (WDS) apart from having the lowest moisture content compared to all other sites it was more contaminated than ODA, and toilet sites. This was because all the waste materials including contaminated soil of the backyard site after being swept they are usually disposed/thrown into the WDS. This provided the chance for recovery of most eggs which some of them might had not originated from the WDS.

The presence of the four species of human parasitic helminthes in the examined backyard, ODA, toilets and WDS indicate the potential health risk among the oral faecal age children. Furthermore, backyard samples being more contaminated poses more health risks because it is the place where kitchen and other households refuse are damped. It is the place grown with subsistence seasonal and or annual horticultural crops like amaranthus, spinach, carrots, chinese, and cucubitaceae to mention a few. While these vegetables are consumed daily, its preparation again is questionable, thus subjecting human onto the cycle of reinfection by geohelminths eggs.

\section{CONCLUSIONS}

This study aimed at examining the extent of Taenia spp. eggs in soil samples collected from rural settings of Iringa region. All sites i.e. backyard, ODA, toilets and WDS revealed none of the Taenia spp. Eggs, though those found were difficult to identify due to absorption of the flotation fluid which made them dark with difficulties to see the innermost structures. However, in view of their sizes (30 - 40 microns in diameter) these eggs were considered to be of Taenia spp. Furthermore the findings revealed that the environment of Izazi village was more contaminated by geohelminths eggs (19.4\%) than that of Migoli village $(12.1 \%)$. Among the four sampling sites of the study area, the Backyard site was the most contaminated by $30.1 \%$ followed by Waste disposal sites by $25.7 \%$ then Open defeacation areas by $24.0 \%$ and the least contaminated was Toilet site by $20.2 \%$. Moisture content was found to favor growth, development, spread and transmission of geo-helminths eggs. Most eggs were recovered from Backyard soil samples with the highest moisture content of $1.11 \%$.

\section{CONFLICT OF INTEREST}

The authors confirm that this article content has no conflicts of interest.

\section{ACKNOWLEDGEMENTS}

The authors acknowledge Welcome Trust through Afrique One - University of Dar es Salaam Project for financial support.

\section{REFERENCES}

[1] A. Flisser, A. Reid, E. Garcia-Zepeda, and D.P. McManus, "Specific detection of Taenia saginata eggs by DNA hybridization". Lancet, vol. II, pp. 1429-1430, 1988.

[2] AE. Gonzalez, H.H. Garcia, R.H. Gilman, and V.C. Tsang, "Cysticercosis Working Group in Peru. Control of Taenia solium". Acta Tropica, vol. 87, pp. 103-109, 2003. 
[3] S. Abseir, C. Epe, T. Schnieder, G. Klein, and M. Kuhne, "Visual diagnosis of Taenia saginata cysticercosis during meat inspection: is it unequivocal? Parasitology". Research, vol. 99, pp. 405-409, 2006.

[4] H.H. Garcia, O.H. Del. Brutto, T.E. Nash, A.C. White, V.C. Jr Tsang, and R.H. Gilman, "New concepts in the diagnosis and management of neurocysticercosis (Taenia solium)". American Journal of Tropical Medicine and Hygiene, vol. 72, pp. 3-9, 2005.

[5] E.A. Dirk, U.B. Carlo, B.C. Albino, O. Franc, A. Meslin, and S. Lorenzo, "The control of human (neuro)cysticercosis: which way forward?" Acta Tropica, vol. 87, pp. 177-182, 2003.

[6] I.K. Phiri, H. Ngowi, S.M.S. Afonso, E. Matenga, M. Boa, S. Mukaratirwa, S.M. Githigia, M.K. Saimo, C.S. Sikasunge, N. Maingi, G.W. Lubega, A. Kassuku, L.M. Michael, S. Siziya, R.C. Krecek, E. Noormahomed, M. Vilhena, P. Dorny and A.L. III Willingham, "The emergence of Taenia solium cysticercosis in Eastern and Southern Africa as a serious agricultural problem and public health risk". Acta Tropica, vol. 87, pp. 13-23, 2003.

[7] M. Boa, S. Mukaratirwa, A.L. Willingham, and M.V. Johansen. "Regional action plan for combating Taenia solium cysticercosis/ taeniosis in Eastern and Southern Africa". Acta Tropica, vol. 87(1), pp. 183-186, 2003.

[8] H.A. Ngowi, A.A. Kassuku, H. Carabin, J.E.D. Mlangwa, M.R.S Mlozi, B.P. Mbilinyi, and A.L. III Willingham, "Spatial Clustering of Porcine Cysticercosis in Mbulu District, Northern Tanzania", PLoS Neglected Tropical Diseases, vol. 4(4), p. e652, 2010.

[9] H.A. Ngowi, H. Carabin, A.A. Kassuku, M.R.S. Mlozi, J.E.D. Mlangwa, and A.L. III Willingham, "A health-education intervention trial to reduce porcine cysticercosis in Mbulu District, Tanzania", Preventive Veterinary Medicine, vol. 85, pp. 52-67, 2008.

[10] K. Matsuo, and H. Kamiya, "Modified Sugar Centrifugal Flotation Technique for Recovering Echinococcus multilocularis Eggs from Soil". Journal of Parasitology, vol. 91(1), pp. 208-209, 2005.

[11] M.O. Harhay, J. Horton, and P.L. Olliaro, "Epidemiology and control of human gastrointestinal parasites in children". Expert Review of Anti-infective Therapy, vol. 8(2), pp. 219-324, 2010.

[12] P.R. Murray, K.S. Rosenthal, and M.A. Pfaller, "Medical Microbiology", $5^{\text {th }}$ ed. Elsevier Mosby: United States, 2005.

[13] D.P. Widjana, and P. Sutisna, "Prevalence of soil-transmitted helminth infections in the rural population of Bali, Indonesia", Southeast Asian Journal Tropical Medicine Public Health, vol. 31(3), pp. 454-459, 2000.

[14] K.J. Ndamukong, M.A. Ayuk, J.S. Dinga, T.N. Akenji, and V.A. Ndiforchu, "The pattern of soil- transmitted nematode infections in primary school children of the Kumba Health District, South-West Cameroon", African Journal Health Science, vol. (3-4), pp. 103$106,2000$.
[15] I.H. Nock, N. Duniya, and M. Galadima, "Geo-helminths eggs in the soil and stool of pupils of some primary schools in Samaru, Zaria Nigeria". The Nigeria Journal Parasitology, vol. 24, pp. 115$122,2003$.

[16] M.C. Chukwuma, I.M. Ekejindu, N.R. Agbakoba, D.A. Ezeagwuna, I.C. Anaghalu, and D.C. Nwosu. "The Prevalence and Risk Factors of Geohelminth Infections among Primary School Children in Ebenebe Town, Anambra State, Nigeria", Middle-East Journal of Scientific Research, vol. 4(3), pp. 211-215, 2009.

[17] M.R. Gatlin, C.L. Black, P.N. Mwinzi, W.E. Secor, D.M. Karanja, and D.G. Colley. "Association of the gene polymorphisms IFN gamma +874 , IL-13 -1055 and IL-4 -590 with patterns of reinfection with Schistosoma mansoni". PLoS Neglected Tropical Diseases, vol. 3(2), p. e375, 2009.

[18] D.W. Crompton, "How much human helminthiasis is there in the world?" The Journal of Parasitology, vol. 85(3), pp. 397-403, 1999.

[19] K.C. Kwashie, "Microbial Analysis of Soil Samples in a Wastewater Irrigated Vegetable Production Site", Thesis. Department of Theoretical and Applied Biology, Kwame Nkrumah University of Science and Technology (KNUST), Kumasi, 2011.

[20] R. Speare, "Identification of species of Strongyloides". In: Strongyloidiasis, a major roundworm infection of man, D.I. Grove, Ed.; Taylor, and Francis: London 1989, pp. 11-83.

[21] C.M. Hendrix, B.L. Blagburn, and D.S. Lindsay, "Whipworms and intestinal threadworms". Veterinary Clinical North American Small Animal Practical, vol. 17 (6), pp. 1355-1375, 1987.

[22] J. Blaszkowska, P. Kurnatowski, and P. Damiecka, "Contamination of the soil by eggs of geohelminths in rural areas of Lodz district (Poland)", Helminthologia Journal, vol. 48(2), pp. 67-76, 2011.

[23] M. Cheesbrough, District laboratory practice in tropical countries. Cambridge University Press: Cambridge, 2000, pp. 209-215.

[24] M,S. Chan, "The global burden of intestinal nematodes infectionsfifty years on", Parasitology Today, vol. 13, pp. 438-443, 1997.

[25] M. Huerta, R. Avila, I.H. Jiménez, R. Díaz, and J. Díaz, "Parasite contamination of soil in households of a Mexican rural community endemic for neurocysticercosis". Transactions of the Royal Society and Tropical Medicine Hygiene, vol. 102(4), pp. 374-379, 2008.

[26] J.V. Mbuh, N.H. Ntonifor, and J. Ojong, "The epidemiology of soil-transmitted helminths and protozoan infections in south-west Cameroon", Journal of Helminthology, vol. 86(1), pp. 30-37, 2012.

[27] E.C. Amadi, and E.C. Uttah, "Bionomics of Geohelminth Nematodes in Contaminated Foci in Parts of Abua Communities, Niger Delta, Nigeria (A)", Journal of Applied Science and Environment Management, vol. 14 (2), 61-64, 2010. 